\title{
Effect of Variation of Zinc Content and Sintering Temperature on Structural Properties of Some Ferrite Materials
}

\author{
A.I. $\mathrm{ABD}^{a, *}$, A.L. $\mathrm{ABED}^{b}$ AND D.S. AHMED ${ }^{a}$ \\ ${ }^{a}$ Applied Sciences department, University of Technology, Baghdad, Iraq \\ ${ }^{b}$ Nanotechnology and Advanced Materials Research Center, University of Technology, Baghdad, Iraq \\ In this paper sol-gel method was used to synthesize $\mathrm{Cu}_{1-x} \mathrm{Zn}_{x} \mathrm{Fe}_{2} \mathrm{O}_{4}$ samples. Nitrates of magnesium, zinc \\ and iron with purity of $97.00 \%$ were mixed with $80 \mathrm{ml}$ of distilled water. To homogenize the resulting solution a \\ constant stirring was used. The $\mathrm{pH}$ of the mixture was adjusted to 7 by ammonia while heating on a hot plate at \\ $60{ }^{\circ} \mathrm{C}$ for 30 min. This procedure was followed by raising the temperature to $80^{\circ} \mathrm{C}$ and continuous heating for $3 \mathrm{~h}$ to \\ form the gel, which was dried at $120^{\circ} \mathrm{C}$ to a complete burn out resulting in formation of fluffy structure. The fluffy \\ structure was ground for $3 \mathrm{~min}$ using electric grinder to form fine ferrite powder. Powder was calcined at $500^{\circ} \mathrm{C}$ \\ for $4 \mathrm{~h}$ and sintered at 1000, 1100 and $1200^{\circ} \mathrm{C}$. The influence of sintering temperature on physical and magnetic \\ properties of samples was studied by measurement of the absorbance of microwaves and the attenuation coefficient. \\ The structure and morphology of prepared samples have been determined using XRD analysis and SEM.
}

DOI: 10.12693/APhysPolA.134.139

PACS/topics: Cu-Zn ferrite, sol-gel method, ferromagnetic materials, magnetic properties

\section{Introduction}

Ferrites with spinel structures are essential materials for solid state microwave applications and for soft magnetic applications. Suitability of these materials depends on both the intrinsic features of material and the effects of grain sizes.

Ferrites are usually non-conductive ferrimagnetic ceramic compound materials that include oxygen and two magnetic ions to produce spontaneous magnetization, having chemical formula of $\mathrm{AB}_{2} \mathrm{O}_{4}$, where $\mathrm{A}$ and $\mathrm{B}$ represent various metal cations, and consisting of different mixtures of iron oxide, like hematite $\mathrm{Fe}_{2} \mathrm{O}_{3}$ or magnetite $\mathrm{Fe}_{3} \mathrm{O}_{4}$ and the oxides of other metals such as $\mathrm{NiO}, \mathrm{CuO}$, $\mathrm{ZnO}, \mathrm{MnO}$ and $\mathrm{CoO}[1]$.

There are many methods and techniques used to prepare ferrites, such as conventional ceramic methods, sol-gel methods, pulsed laser deposition techniques, hydrothermal processes and many other methods. A range of other methods were considered to maintain small grain sizes of the material during synthesis of ferrites with the spinel structure $[2,3]$.

Currently, ferrite materials become important in economic and engineering applications because of their exceptional physical features [4]. Basically, TV sets, portable radios and long distance carrier telephone circuits employ ferrite cores in filters, antennas and transformers [5]. In particular, soft ferrites represent the most commonly used materials due to their low cost and good performance in high frequency applications.

$\mathrm{Cu}-\mathrm{Zn}$ ferrite has many important applications in this context [6]. The present work is dealing with synthesis

*corresponding author; e-mail: atheer_alkfage@yahoo.com and characterization of nanocomposite $\mathrm{Cu}_{1-x} \mathrm{Zn}_{x} \mathrm{Fe}_{2} \mathrm{O}_{4}$ ferrite samples synthesized using sol-gel method and subsequently sintered at different temperatures (1000, 1100 , and $1200^{\circ} \mathrm{C}$ ) after heating with the heating rate of $50^{\circ} \mathrm{C} / \mathrm{min}$. Samples were characterized using X-ray diffraction to determine the structures of samples, using measurement of the density, and using scanning electron microscopy (SEM), to characterize the crystal sizes.

\section{Experimental part}

In this study the raw materials with very high purity were chosen to avoid any influence of impurities on the compound properties. Table I shows the purity of the raw materials that had been used in this work to prepare samples using the sol-gel method. In this work $\mathrm{Cu}_{1-x} \mathrm{Zn}_{x} \mathrm{Fe}_{2} \mathrm{O}_{4}$ was prepared using appropriate amounts of nitrates and citric acid. The raw materials were mixed with $80 \mathrm{ml}$ of distilled water in a beaker, and the mixture was homogenized by continuous stirring using a magnetic hot plate stirrer (model LMS-1003).

TABLE I

The purity of the raw materials used in sol-gel method.

\begin{tabular}{c|c}
\hline \hline Raw material & Purity \\
\hline $\mathrm{Cu}\left(\mathrm{NO}_{3}\right)_{2} \cdot 6 \mathrm{H}_{2} \mathrm{O}$ & $99 \%$ \\
$\mathrm{Zn}\left(\mathrm{NO}_{3}\right)_{2} \cdot 6 \mathrm{H}_{2} \mathrm{O}$ & $98 \%$ \\
$\mathrm{Fe}\left(\mathrm{NO}_{3}\right)_{3} \cdot 9 \mathrm{H}_{2} \mathrm{O}$ & $97 \%$
\end{tabular}

The $\mathrm{pH}$ of solution was adjusted to 7 by adding ammonia to the solution and by heating on a heater at $60^{\circ} \mathrm{C}$ for $30 \mathrm{~min}$. Then temperature was raised to $80^{\circ} \mathrm{C}$ and maintained for $3 \mathrm{~h}$, which had lead to transformation of the the sol into gel. The gel was dried at $120^{\circ} \mathrm{C}$ until burning in a self-propagating combustion with formation of a fluffy loose material. 
The fluffy structure was then ground to form ferrite powder using an electric grinder for $3 \mathrm{~min}$. The burn ash was calcined at $500^{\circ} \mathrm{C}$ for $3 \mathrm{~h}$ to achieve better crystallization and a homogeneous cation distribution in the spinel crystallites.

Powders were mixed with 6 wt. $\%$ of glycerin with purity of $88 \%$, used as a binder. The powder was then pressed at $10^{2} \mathrm{MPa}$ by a hydraulic press and a die to obtain samples in the form of parallelograms with dimensions of $2.4 \times 1.2 \times 1.2 \mathrm{~cm}^{3}$.

Three samples were made for each formula of the ferrite. The samples were sintered for $6 \mathrm{~h}$ at three sintering temperatures $\left(1000,1100,1200^{\circ} \mathrm{C}\right)$ after heating with the heating rate of $50^{\circ} \mathrm{C} / \mathrm{min}$ ), and then were left to cool inside the furnace. Afterwards the samples were processed to reduce their dimensions to $2.23 \times 1.0 \times 1.0 \mathrm{~cm}^{3}$. The auto combustion synthesis presented in the diagram in Fig. 1 shows the steps of synthesis of the ferrite powders.

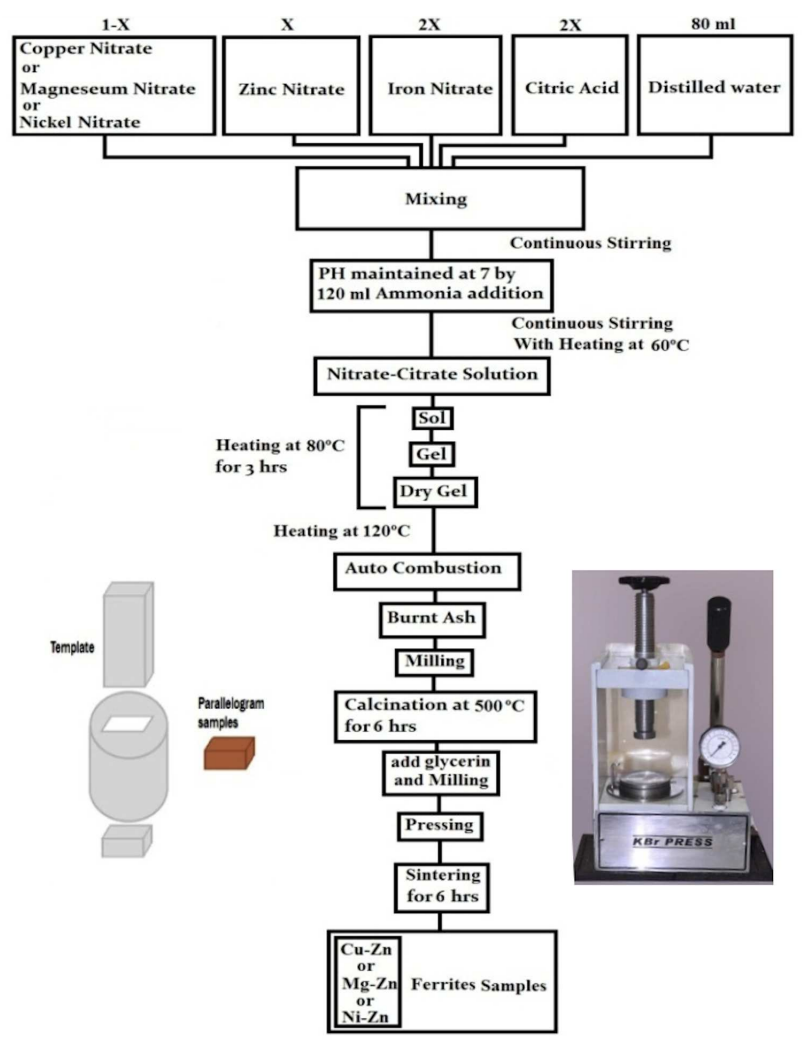

Fig. 1. Diagram showing the steps of preparation of the ferrite powders by the sol-gel method.

The structures of the synthesized powder were characterized by X-ray diffraction (XRD, 6000-Shimadzu X-Ray diffractometer). The microstructure of $\mathrm{Cu}_{1-x} \mathrm{Zn}_{x} \mathrm{Fe}_{2} \mathrm{O}_{4}$ was evaluated by scanning electron microscopy (SEM, VEGA Easy Probe) and by measurement of physical properties of samples.

\section{Results and discussion}

The X-Ray analysis was carried out for the sample with $x=0.4$. The results show a perfect match with the international standard (ASTM), as shown in Table II for sample sintered at $1200^{\circ} \mathrm{C}$, which indicates the formation of cubic spinel structure [7] in the sample. All samples were poly-crystalline with the preferred plain of (211). The X-ray diffraction was measured in the range of the Bragg angles of $2 \theta=10^{\circ}-50^{\circ}$. The diffraction peaks shown in Fig. 2 correspond to Miller indices $(h, k, l)$ of (111), (200), (202), (220), and (211).
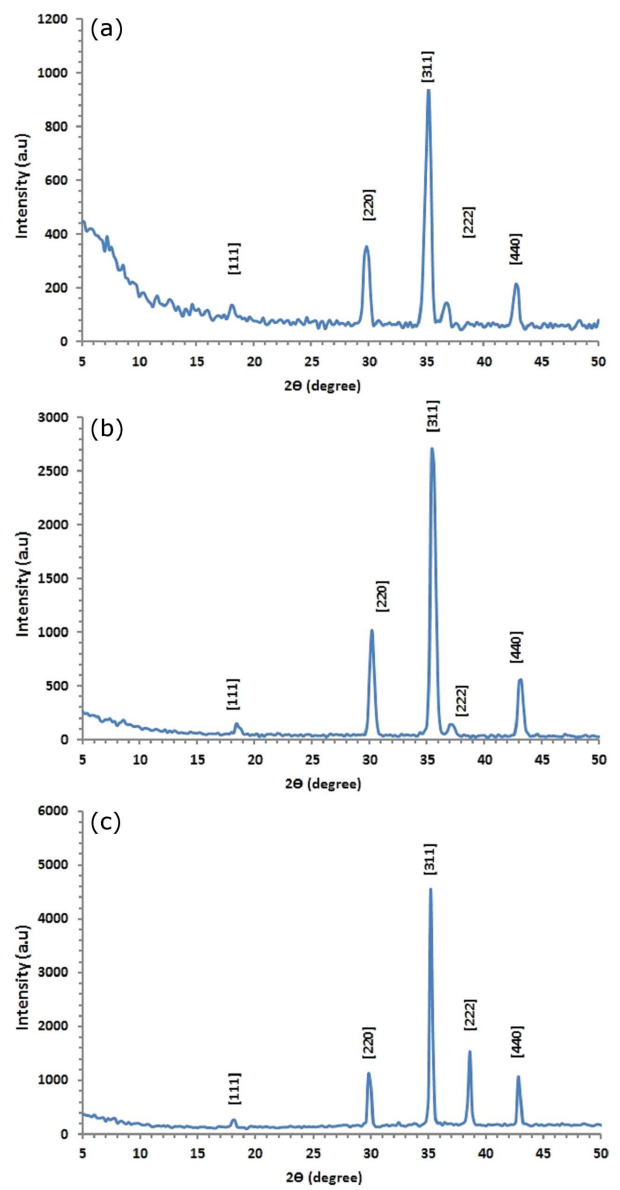

Fig. 2. XRD patterns of $\mathrm{Cu}_{0.6} \mathrm{Zn}_{0.4} \mathrm{Fe}_{2} \mathrm{O}_{4}$ samples prepared using sol-gel method and sintered at $1000^{\circ} \mathrm{C}$ (a), $1100^{\circ} \mathrm{C}(\mathrm{b})$, and $1200^{\circ} \mathrm{C}(\mathrm{c})$.

The lattice parameter $a$ of the samples was calculated using Eq. (1) [8] and the average grain size $g$ was calculated using Scherer's formula shown in Eq. (2) [9]. The micro strain $\delta$, caused by the sintering stage was calculated using Eq. (3) [10, 11]:

$$
\begin{aligned}
a & =d \sqrt{h^{2}+k^{2}+l^{2}}, \\
g & =\frac{0.94 \lambda}{\Delta \cos (\theta)}, \\
\delta & =\left|\frac{a_{\mathrm{ASTM}}-a_{\mathrm{XRD}}}{a_{\mathrm{ASTM}}}\right| \times 100 \% .
\end{aligned}
$$

Here $\Delta$ is full width at half maximum in radian units, $\lambda$ is wavelength of $1.5406 \AA$ and $\delta$ is the micro strain. 
Structure parameters of $\mathrm{Cu}_{0.6} \mathrm{Zn}_{0.4} \mathrm{Fe}_{2} \mathrm{O}_{4}$ samples prepared using sol-gel method and sintered at $1200{ }^{\circ} \mathrm{C}$.

TABLE II

\begin{tabular}{c|c|c|c|c|c|c|c|c}
\hline \hline$[h k l]$ & $2 \theta\left[^{\circ}\right]$ exp. & $d[\AA]$ exp. & $2 \theta\left[^{\circ}\right]$ ASTM & $d[\AA]$ ASTM & $I / I_{0}$ & FWHM $\left[{ }^{\circ}\right]$ & Grain size $[\AA]$ & $\delta[\%]$ \\
\hline$[111]$ & 18.662 & 4.750 & 18.508 & 4.790 & 5 & 0.153 & 53.514 & 0.820 \\
{$[200]$} & 30.421 & 2.935 & 30.558 & 2.923 & 25 & 0.172 & 46.469 & 0.442 \\
{$[211]$} & 35.765 & 2.508 & 35.861 & 2.502 & 100 & 0.151 & 52.225 & 0.261 \\
{$[202]$} & 37.385 & 2.403 & 37.121 & 2.419 & 11 & 0.135 & 57.962 & 0.677 \\
{$[220]$} & 43.372 & 2.084 & 43.767 & 2.066 & 20 & 0.154 & 49.871 & 0.869
\end{tabular}

Figure 3 shows scanning electron microscope images of $\mathrm{Cu}_{1-x} \mathrm{Zn}_{x} \mathrm{Fe}_{2} \mathrm{O}_{4}$ ferrite prepared by the sol-gel method and sintered at $1200{ }^{\circ} \mathrm{C}$. These images show the shape and size of the grains in the sample. It can be seen that the gain size grows continuously and that the considered sintering temperature exhibits a large effect on the structure.
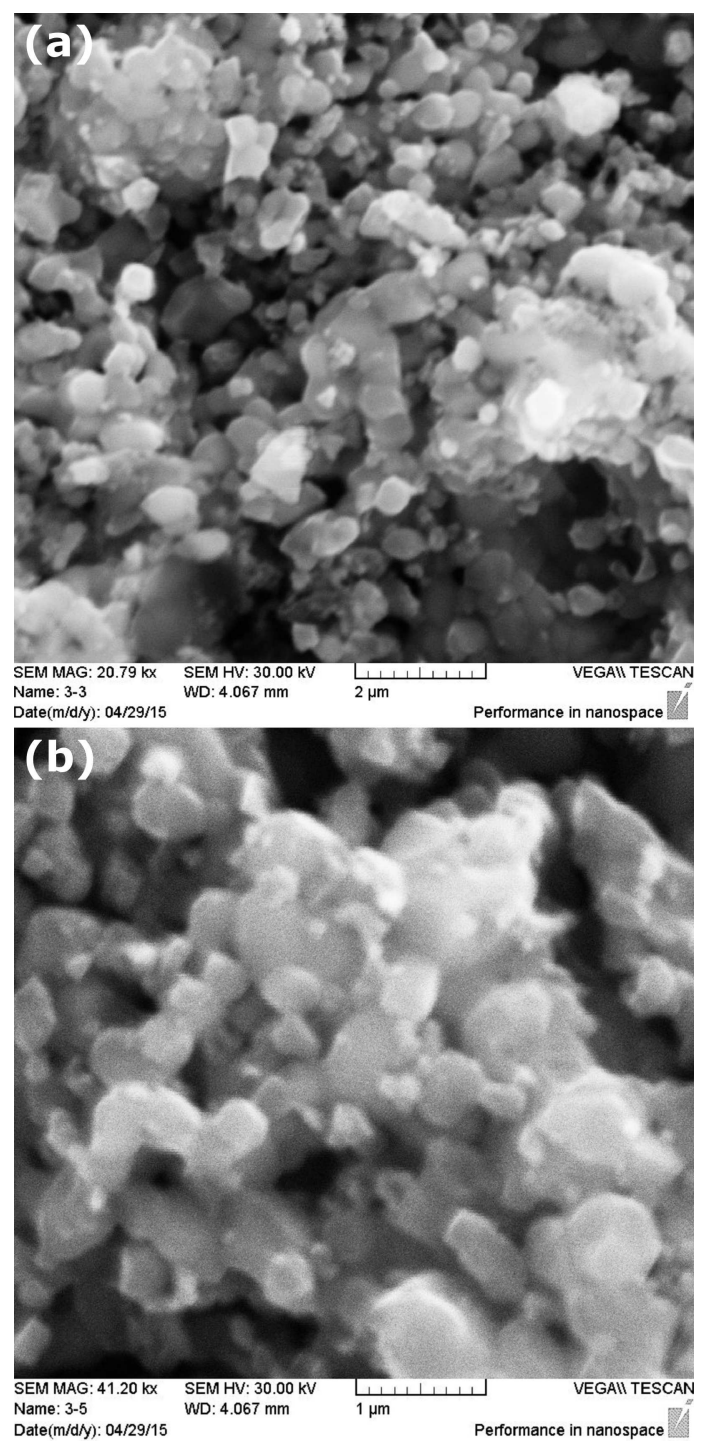

Fig. 3. SEM images of $\mathrm{Cu}_{0.6} \mathrm{Zn}_{0.4} \mathrm{Fe}_{2} \mathrm{O}_{4}$ sample sintered at $1200^{\circ} \mathrm{C}$ at two values of magnification.

The mechanism of grain growth depends on the diffusion coefficient, on sintering temperature and on con- centration of different ions. In the sintering method it is defined by compromise between the driving force of grain boundary movement and the retarding force of pores and inclusions. The strength of driving force depends on diffusivity of ions essential for grain growth [12].

The absorption tests of $\mathrm{Cu}-\mathrm{Zn}$ ferrite materials were carried out for all $x$ values, $x=0.4$ and 0.6 , sintered at 1000,1100 , and $1200^{\circ} \mathrm{C}$, in the $\mathrm{X}$-band range of 8-12.5 GHz. The thickness of samples was $10 \mathrm{~mm}$. In this study the attenuation coefficient and absorbance were calculated from the scattering parameters $S 11$ and $S 21$. The scattering parameters are always measured in decibel units $(\mathrm{dB})$. To calculate the coefficients of reflection and transmission one must use Eqs. (4) and $(5)[14,15]$ :

$$
\begin{aligned}
& R(\%)=10^{\left(\left.S 11\right|_{d B} / 10\right)}, \\
& T(\%)=10^{\left(\left.S 21\right|_{d B} / 10\right)} .
\end{aligned}
$$

The absorbance $(\%)$ can be calculated by substituting the results of Eqs. (4) and (5) in Eq. (6)

$$
\text { Absorbance }=1-R^{2}-T^{2} \text {. }
$$

The attenuation coefficient or reflection loss in dB units is calculated using Eq. (7) [15]

Attenuation coefficient $=-20 \log |S 11|$.

As shown in Fig. 4a, there is one resonance peak for the $\mathrm{Cu}_{0.6} \mathrm{Zn}_{0.4} \mathrm{Fe}_{2} \mathrm{O}_{4}$ sample sintered at $1200^{\circ} \mathrm{C}$. This peak is the largest in this research and its form is identical to that of a ferrite. The best value of reflection coefficient was obtained in sample sintered at $1200^{\circ} \mathrm{C}$, which is due to presence of ferrite phase in this sample, as well as to increasing density of this material caused by the reduced porosity. The maximum value of reflection coefficient in this sample is $-56.71 \mathrm{~dB}$ at frequency of $8.60 \mathrm{GHz}$.

Figure $4 \mathrm{~b}$ shows that transmission coefficients of samples sintered at $1200^{\circ} \mathrm{C}$ and $1100^{\circ} \mathrm{C}$ overlap, which confirms that synthesis of ferrite occurs between these two temperatures. Figure $4 \mathrm{c}$ shows the variation of the attenuation coefficient with frequency for $\mathrm{Cu}_{0.6} \mathrm{Zn}_{0.4} \mathrm{Fe}_{2} \mathrm{O}_{4}$.

Figure $4 \mathrm{~d}$ shows that the values of the absorbance are very high, especially in sample sintered at $1200^{\circ} \mathrm{C}$. The high absorbance bandwidth for this sample is $2.61 \mathrm{GHz}$ in the frequency range of $9.40-12.01 \mathrm{GHz}$ of the X-band region. The high absorbance bandwidth of the sample sintered at $1100^{\circ} \mathrm{C}$ is $1.98 \mathrm{GHz}$ in the frequency range of 8.81-10.79 GHz. The other calculated parameters of $\mathrm{Cu}-\mathrm{Zn}$ ferrites are presented in Tables III-VI. 
(a)

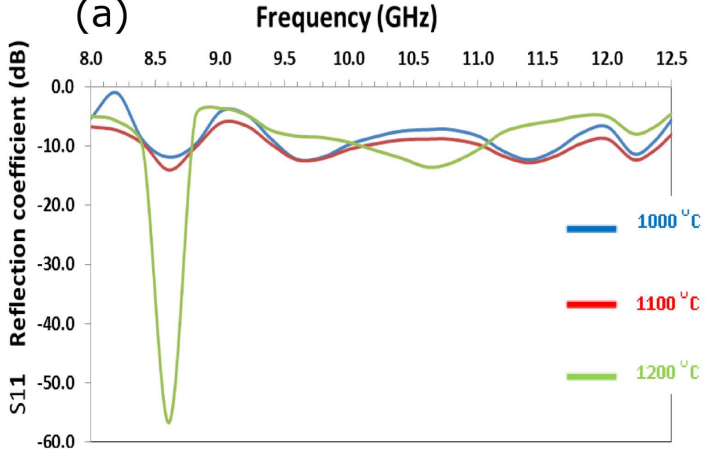

(c) Frequency (GHz)

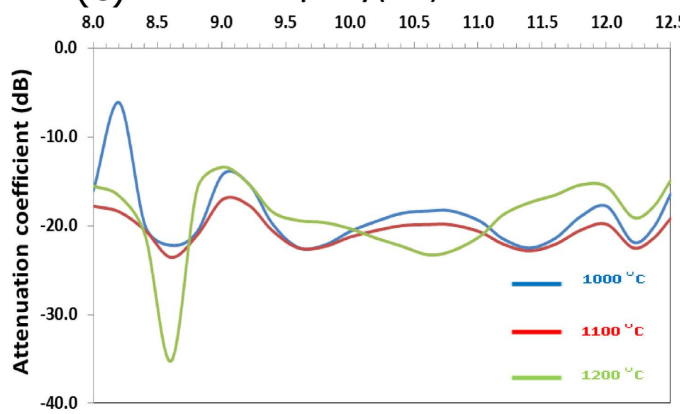

(b) Frequency (GHz)

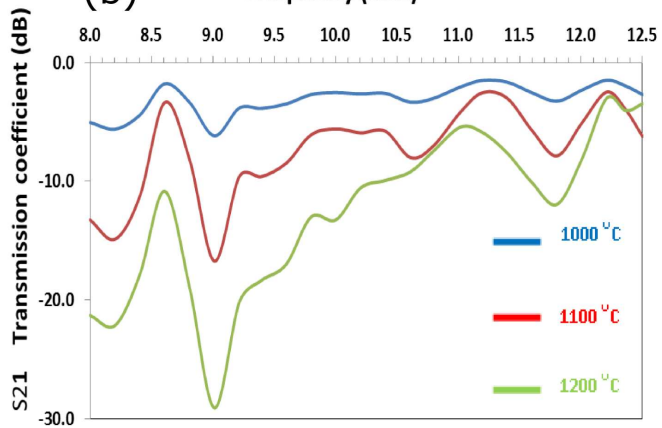

(d)

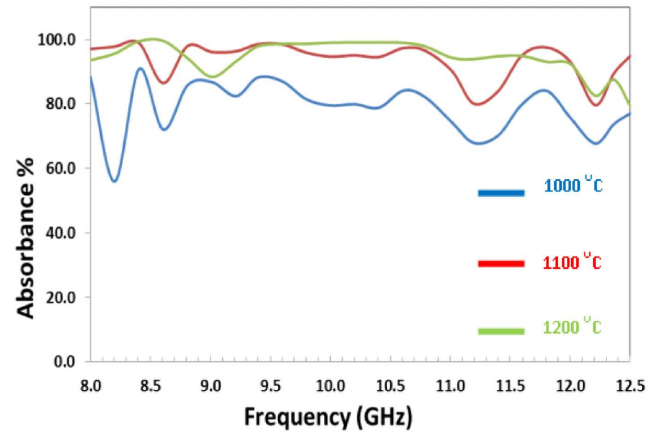

Fig. 4. Reflection coefficient (a), transmission coefficient (b), attenuation coefficient (c) and absorbance (d) as functions of frequency for $\mathrm{Cu}_{0.6} \mathrm{Zn}_{0.4} \mathrm{Fe}_{2} \mathrm{O}_{4}$ samples prepared using sol-gel method.

TABLE III

Data regarding the coefficient of reflection $S 11$ for $\mathrm{Cu}_{1-x} \mathrm{Zn}_{x} \mathrm{Fe}_{2} \mathrm{O}_{4}$ samples prepared using sol-gel method.

\begin{tabular}{c|c|c|c|c|c}
\hline \hline Formula & $\begin{array}{c}\text { No. of resonance } \\
\text { peaks }\end{array}$ & $\begin{array}{c}\text { Sintering } \\
\text { temper. }\left[{ }^{\circ} \mathrm{C}\right]\end{array}$ & $\begin{array}{c}\text { Peak value } \\
{[\mathrm{dB}]}\end{array}$ & $\begin{array}{c}\text { Peak freq. } \\
{[\mathrm{GHz}]}\end{array}$ & $\begin{array}{c}\text { Curve overlap } \\
\text { temperature range }\left[{ }^{\circ} \mathrm{C}\right]\end{array}$ \\
\hline \multirow{2}{*}{$\mathrm{Cu}_{0.4} \mathrm{Zn}_{0.6} \mathrm{Fe}_{2} \mathrm{O}_{4}$} & 0 & 1000 & - & - & 1100 and 1200 \\
& 1 & 1050 & -20.59 & 11.01 & 11.01 \\
$\mathrm{Cu}_{0.6} \mathrm{Zn}_{0.4} \mathrm{Fe}_{2} \mathrm{O}_{4}$ & 1 & 1100 & -26.37 & 1100 and 1200 \\
& 1 & 1000 & -11.90 & 8.60 & 8.60 \\
\end{tabular}

TABLE IV

Data regarding the coefficient of transmission $S 21$ for $\mathrm{Cu}_{1-x} \mathrm{Zn}_{x} \mathrm{Fe}_{2} \mathrm{O}_{4}$ samples prepared using sol-gel method.

\begin{tabular}{|c|c|c|c|c|c|}
\hline Formula & $\begin{array}{c}\text { No. of resonance } \\
\text { peaks }\end{array}$ & $\begin{array}{c}\text { Sintering } \\
\text { temper. }\left[{ }^{\circ} \mathrm{C}\right]\end{array}$ & $\begin{array}{c}\text { Peak value } \\
{[\mathrm{dB}]}\end{array}$ & $\begin{array}{c}\text { Peak freq. } \\
{[\mathrm{GHz}]}\end{array}$ & $\begin{array}{c}\text { Curve overlap } \\
\text { temperature range }\left[{ }^{\circ} \mathrm{C}\right]\end{array}$ \\
\hline \multirow{3}{*}{$\mathrm{Cu}_{0.4} \mathrm{Zn}_{0.6} \mathrm{Fe}_{2} \mathrm{O}_{4}$} & 1 & 1000 & -7.63 & 9.01 & \multirow{3}{*}{1100 and 1200} \\
\hline & 1 & 1100 & -10.82 & 9.01 & \\
\hline & 1 & 1200 & -17.72 & 9.01 & \\
\hline \multirow{3}{*}{$\mathrm{Cu}_{0.6} \mathrm{Zn}_{0.4} \mathrm{Fe}_{2} \mathrm{O}_{4}$} & 1 & 1000 & -6.16 & 9.01 & \multirow{3}{*}{ all } \\
\hline & 3 & 1100 & $\begin{array}{c}-14.88 \\
-16.72 \\
-7.85\end{array}$ & $\begin{array}{l}8.20, \\
9.01, \\
11.80\end{array}$ & \\
\hline & 3 & 1200 & $\begin{array}{l}-22.10 \\
-29.08 \\
-11.94\end{array}$ & $\begin{array}{l}8.20, \\
9.01, \\
11.80\end{array}$ & \\
\hline
\end{tabular}


Data regarding the coefficient of attenuation for $\mathrm{Cu}_{1-x} \mathrm{Zn}_{x} \mathrm{Fe}_{2} \mathrm{O}_{4}$ samples prepared using sol-gel method.

TABLE V

\begin{tabular}{c|c|c|c|c|c}
\hline \hline Formula & $\begin{array}{c}\text { No. of resonance } \\
\text { peaks }\end{array}$ & $\begin{array}{c}\text { Sintering } \\
\text { temper. }\left[{ }^{\circ} \mathrm{C}\right]\end{array}$ & $\begin{array}{c}\text { Peak value } \\
{[\mathrm{dB}]}\end{array}$ & $\begin{array}{c}\text { Peak freq. } \\
{[\mathrm{GHz}]}\end{array}$ & $\begin{array}{c}\text { Curve overlap } \\
\text { temperature range }\left[{ }^{\circ} \mathrm{C}\right]\end{array}$ \\
\hline \multirow{2}{*}{$\mathrm{Cu}_{0.4} \mathrm{Zn}_{0.6} \mathrm{Fe}_{2} \mathrm{O}_{4}$} & 0 & 1000 & - & - & 1100 and 1200 \\
& 1 & 1100 & -26.77 & 11.01 & 11.01 \\
\hline & 1 & 1200 & -28.75 & 1000 and 1100 \\
$\mathrm{Cu}_{0.6} \mathrm{Zn}_{0.4} \mathrm{Fe}_{2} \mathrm{O}_{4}$ & 1 & 1000 & -22.21 & 8.60 & \\
& 1 & 1100 & -23.56 & 8.60 & 8.60 \\
\end{tabular}

Data regarding the absorbance for $\mathrm{Cu}_{1-x} \mathrm{Zn}_{x} \mathrm{Fe}_{2} \mathrm{O}_{4}$ samples prepared using sol-gel method.

TABLE VI

\begin{tabular}{c|c|c|c|c}
\hline \hline Formula & $\begin{array}{c}\text { Good bandwidth } \\
{[\mathrm{GHz}]}\end{array}$ & $\begin{array}{c}\text { Sintering } \\
\text { temper. }\left[{ }^{\circ} \mathrm{C}\right]\end{array}$ & $\begin{array}{c}\text { Frequency } \\
\text { range [GHz] }\end{array}$ & $\begin{array}{c}\text { Absorbance } \\
\text { range [\%] }\end{array}$ \\
\hline $\mathrm{Cu}_{0.4} \mathrm{Zn}_{0.6} \mathrm{Fe}_{2} \mathrm{O}_{4}$ & 1.4 & 1100 & $9.01-10.41$ & $90.61-94.64$ \\
$\mathrm{Cu}_{0.6} \mathrm{Zn}_{0.4} \mathrm{Fe}_{2} \mathrm{O}_{4}$ & 2.59 & 1200 & $9.40-12.01$ & $94.97-98.19$ \\
\hline & 1.98 & 1100 & $8.81-10.79$ & $94.56-98.51$ \\
\end{tabular}

Density and porosity of the prepared samples.

TABLE VII

\begin{tabular}{c|c|c|c|c}
\hline \hline Formula & Sintering temper. $\left[{ }^{\circ} \mathrm{C}\right]$ & $\rho_{\text {bulk }}\left[\mathrm{g} / \mathrm{cm}^{3}\right]$ & $\rho_{\text {X-ray }}\left[\mathrm{g} / \mathrm{cm}^{3}\right]$ & Porosity $[\%]$ \\
\hline \multirow{2}{*}{$\mathrm{Cu}_{0.4} \mathrm{Zn}_{0.6} \mathrm{Fe}_{2} \mathrm{O}_{4}$} & 1000 & 4.300 & - & - \\
& 1100 & 4.724 & - & - \\
\hline & 1200 & 4.880 & - & - \\
$\mathrm{Cu}_{0.6} \mathrm{Zn}_{0.4} \mathrm{Fe}_{2} \mathrm{O}_{4}$ & 1000 & 4.489 & - & - \\
& 1100 & 4.835 & - & 9.138
\end{tabular}

The density of the prepared samples was measured after sintering. For that the completely dry samples have been weighted, and the dimensions of the samples were measured using a micrometre.

The density $\rho$ of the samples was calculated using formula $\rho=m / V$, where $m$ is mass measured in grams and $V$ is volume measured in $\mathrm{cm}^{3}$. The density was also calculated using Eq. (8) based on X-ray data for the sample with concentration $x=0.4$ sintered at $1200^{\circ} \mathrm{C}$. The porosity was calculated using Eq. (9).

$$
\begin{aligned}
& \rho_{\text {X-ray }}=\frac{8 M}{N_{\mathrm{A}} a^{3}} . \\
& P(\%)=100\left(1-\frac{\rho}{\rho_{\mathrm{X} \text {-ray }}}\right) .
\end{aligned}
$$

Here $\rho$ is bulk density, $\rho_{\mathrm{X} \text {-ray }}$ is the X-ray density, $P$ is porosity, $M$ is molecular mass, $N_{\mathrm{A}}$ is the Avogadro's number and $a$ is lattice constant.

Table VII shows the values of density for all prepared ferrite samples and the value of porosity of sample with concentration $x=0.4$ sintered at $1200^{\circ} \mathrm{C}$. It is seen that samples prepared using sol-gel method are less porous than those prepared by conventional methods.

The results reveal that in thermal treatment of $\mathrm{Cu}_{1-x} \mathrm{Zn}_{x} \mathrm{Fe}_{2} \mathrm{O}_{4}$ samples prepared by sol-gel method the sintering temperature affects the measured density, which increases proportionally with the sintering temperature $[12,13]$. Figure 5 shows that the density is directly proportional to the sintering temperature.

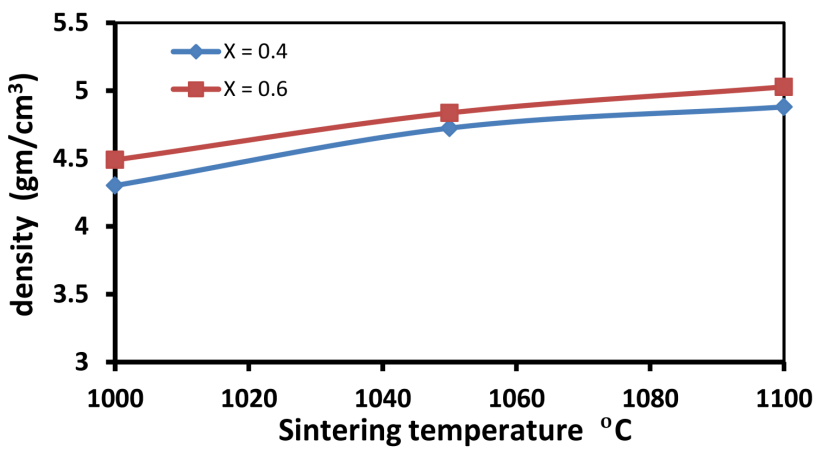

Fig. 5. Effect of sintering temperature on the density of $\mathrm{Cu}_{1-x} \mathrm{Zn}_{x} \mathrm{Fe}_{2} \mathrm{O}_{4}$ samples.

\section{Conclusions}

The best results were obtained after sintering at $1200^{\circ} \mathrm{C}$, which indicates that spinel ferrite needs sintering at temperatures higher than $1000^{\circ} \mathrm{C}$ for the complete 
formation of the ferrite. Such treatment results in better absorbance because high temperature sintering cancels all secondary phases existing within the ferrite. The resonance peaks of three types of the spinel ferrite appear at the same frequencies of $8.60,9.80,10.00$, and $11.60 \mathrm{GHz}$. These peaks remain at the same frequencies for different thicknesses and for all types of ferrite, which indicates that the peaks are not related to thickness. The SEM micrographs reveal smaller average grain size of samples prepared by sol-gel method with higher homogeneity. The density of samples was increasing proportionally with the temperature of the sintering.

\section{Acknowledgments}

The authors are grateful to Nanotechnology and Advanced Material Research Centre, University of Technology, Baghdad, Iraq, for conducting XRD measurements and finally for their efforts in conducting SEM analysis and we are grateful to Applied Science Department for their efforts in conducting the labs of the department.

\section{References}

[1] N. Yahya, A.S.M.N. Aripin, A.A. Aziz, H. Daud, H.M. Zaid, L.K. Pah, N. Maarof, Amer. J. Eng. Appl. Sci. 1, 53 (2008).

[2] R.A. Dunlap, A. Alghamdi, J.W. O'Brien, S.J. Penney, J. Alloys Compd. 365, 84 (2004).
[3] Z. Pędzich, M.M. Bućko, M. Królikowski, M. Bakalarska, J. Babiarz J. Eur. Ceramic Soc. 24, 1053 (2004).

[4] D. El Kony, S.A. Saafan, J. Amer. Sci. 8, 51 (2012).

[5] M. Hashim, Alimuddin, S. Kumar, S. Ali, B.H. Koo, H. Chung, R. Kumar, J. Alloys Compd. 511, 107 (2012).

[6] A. Thakur, P. Mathur, M. Singh, J. Phys. Chem. Solids 68, 378 (2007).

[7] S.A. Mazen, S.F. Mansour, H.M. Zaki, Cryst. Res. Technol. 38, 471 (2003).

[8] B.P. Ladgaonkar, P.P. Bakare, S.R. Sainkar, A.S. Vaingankar, Mater. Chem. Phys. 69, 19 (2001).

[9] C. Gümüs, O.M. Ozkendir, H. Kavak, Y. Ufuktepe, J. Optoelectronics and Advanced Mater. 8(1), 299 (2006).

[10] J.G.M. Van Berkum, A.C. Vermeulen, R. Delhez, T.H. De Keijser, E.J. Mittemeijer, J. Appl. Crys. 27, 345 (1994).

[11] T. Obata, K. Komeda, T. Nakao, H. Ueba, C. Tasygama, J. Appl. Phys. 81, 199 (1997).

[12] K. Raju, C.G. Balaji, P. Venugopal Reddy, J. Magn. Magn. Mater. 354, 383 (2014).

[13] A. Srivastava, P. Singh, M.P. Gupta, J. Mater. Sci. 22, 1489 (1987).

[14] Handbook of Microwave Measurements, ed. M. Sucher, J. Fox, M. Wind, Polytechnic Press of the Polytechnic Institute, Brooklyn 1963.

[15] A. Das, S.K Das, Microwave Engineering, Tata McGraw-Hill Education, New Delhi 2009. 